\title{
Not only a simple milia
}

\section{Sadece basit birr millia değill}

\author{
Işıll Deniz Oğuz ${ }^{1}$, Sevgi Kullaklı ${ }^{1}$, Atıllım Armağan Demirtaş ${ }^{2}$
}

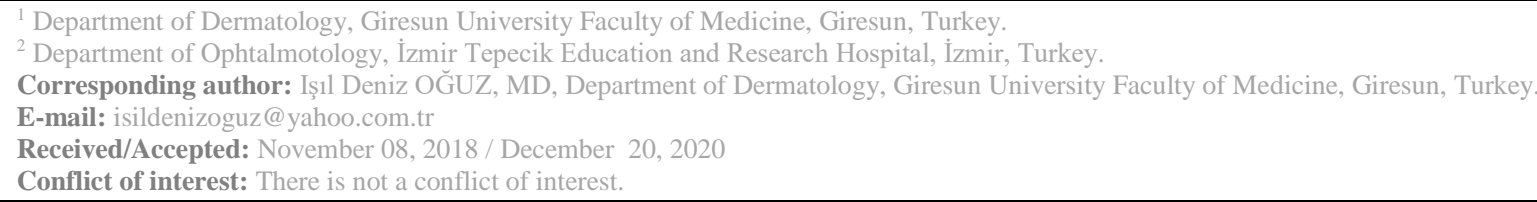

\section{SUMMARY}

Milia is a benign superficial keratinous cyst originates from sebaceous collar of vellus hairs or eccrine ducts. Primary milia may be a component of many genodermatosis. In this case report, we are presenting a family with Bazex-Dupré-Chistol syndrome.

Keywords: Bazex-Dupré-Chistol syndrome, genodermatosis, milia
Iş1 Deniz Oğuz

ORCID IDs of the authors: İ.D.O. 0000-0001-8628-6107

ÖZET

Milia, vellus k1llarının sebase bez bölgesi veya ekrin kanallardan kaynaklanan benign yüzeysel keratinöz bir kisttir. Primer milia, birçok genodermatozun bulgusu olabilir. Bu olgu sunumunda Bazex-Dupré-Chistol sendromu olan bir aileyi sunuyoruz.

Anahtar sözcükler: Bazex-Dupré-Chistol sendromu, genodermatoz, milia

\section{INTRODUCTION}

Milia is a benign superficial keratinous cyst originates from sebaceous collar of vellus hairs or eccrine ducts. Primary milia arises spontaneously. Secondary milia is due to various reasons like dermatologic diseases (epidermolysis bullosa, porphyria cutanea tarda, bullous pemphigoid etc.), medications (topical steroids, cyclosporine, and penicillamine) and trauma (burns, dermabrasion, and radiotherapy). Primary milia may be a component of many genodermatosis ${ }^{1}$. Therefore, physicians should investigate whether an underlying specific condition or genodermatosis is present in patients with milia. In this case report, we are presenting a family with Bazex-DupréChistol syndrome who were admitted to our outpatient clinic with the complaint of milia.

\section{CASES}

Twenty seven year-old female patient (Case 1) with her children 4 year- old girl (Case 2) and 4 month- old boy (Case 3) were admitted to our outpatient clinic with the main complaint of multiple white papules on their face. They have had these lesions since they were three months old and were diagnosed as only simple milia with no morbidity several times in other clinics they previously applied. The mother (Case 1) and her husband were relatives. All of the patients were full term birth by normal delivery.

Taking the family history we noted that 14 other relatives had the same lesions on their faces and of these 4 relatives had a skin cancer (Figure 1). 


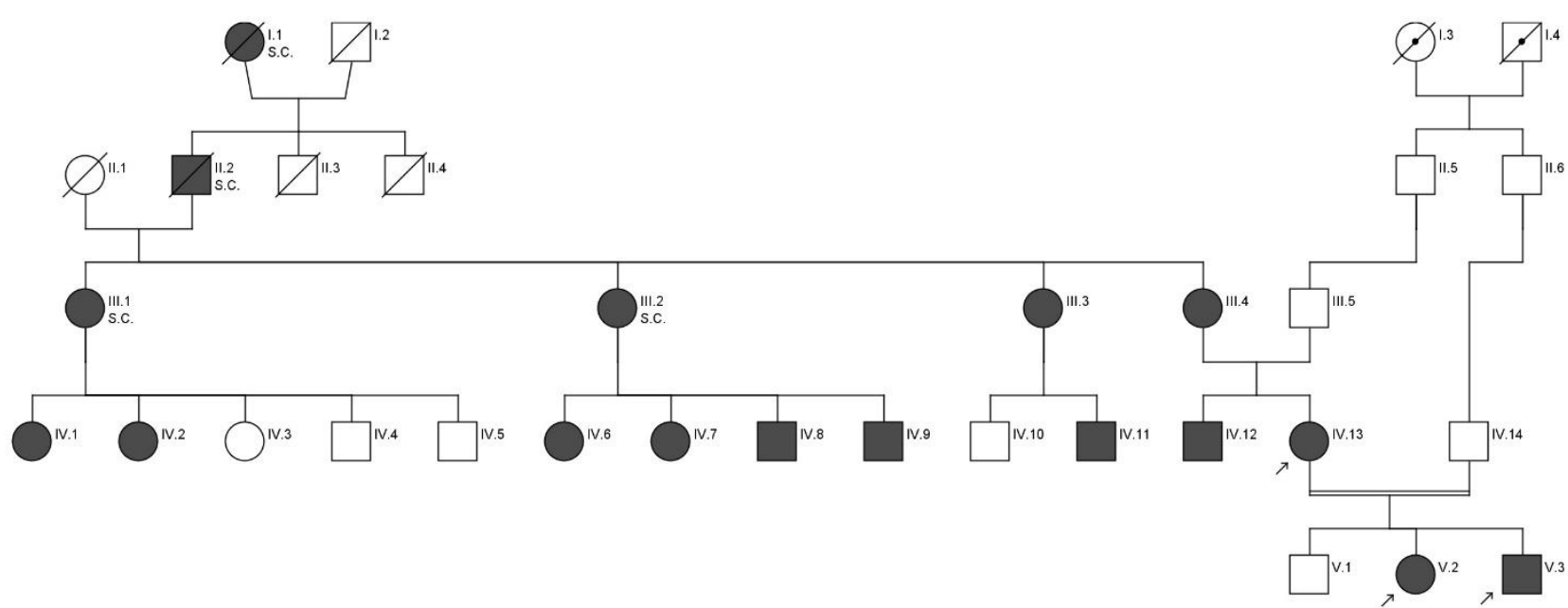

Figure 1: Pedigree shows X-linked dominant inheritance pattern. S.C.: Family members who had skin cancers.

Dermatologic examination of the mother revealed multiple discrete milias on her face particularly on the periorbital skin. The skin and the hair was quite dry and the hair of the scalp was sparse. There were numerous atrophic pits on the dorsum of her hands. The teeth, mucosae and the nails were normal (Figure 2).

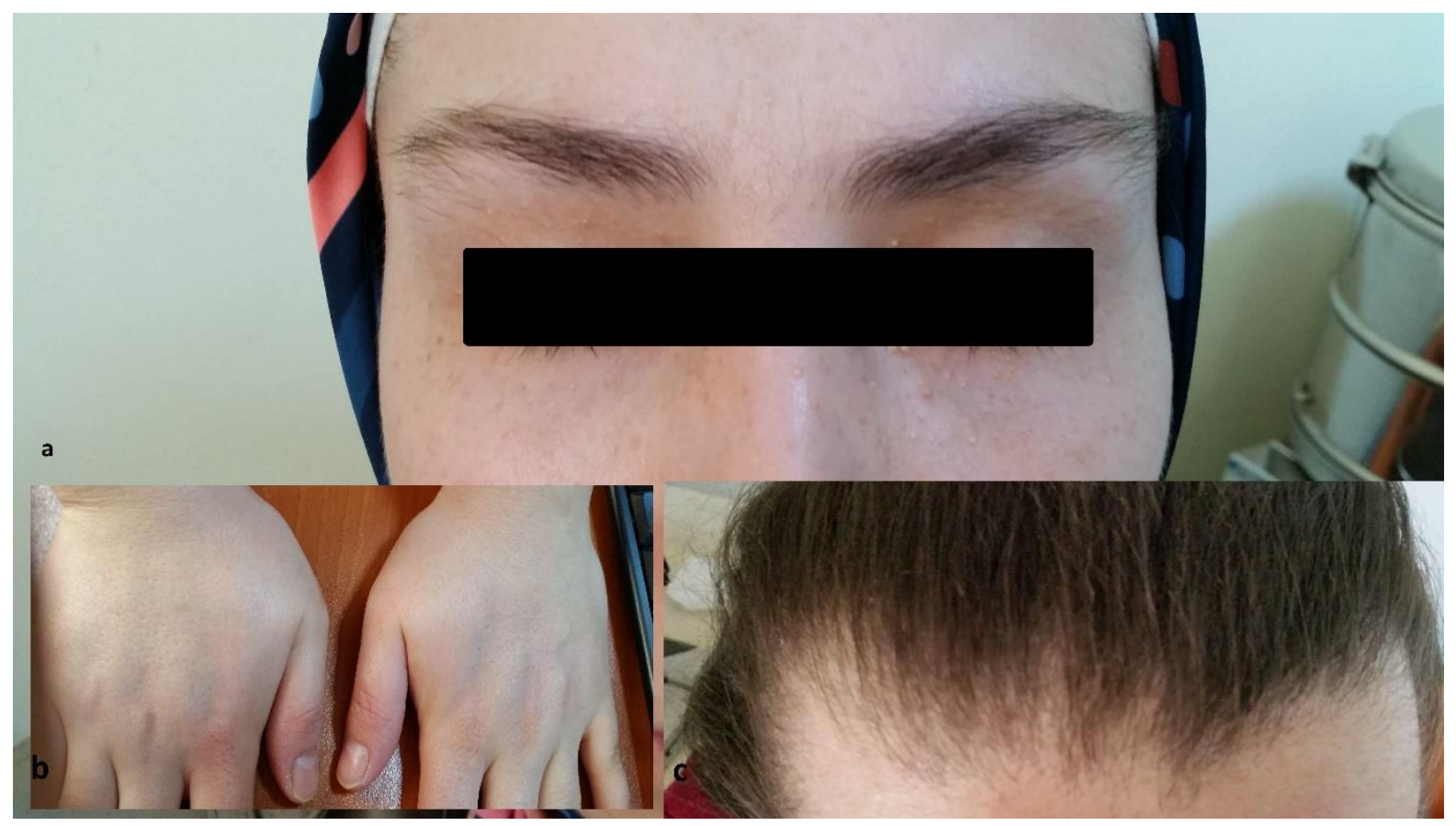

Figure 2. a-c.: Case 1. Multiple milias on the face (a). Follicular atrophoderma on the dorsa of the hands (b). Dry and sparse scalp hair (c).

Her daughter had multiple discrete milias on her face and she had hypotrichosis of hair and eyebrows. Her skin and hair were dry like her mother. Skin of hands was within normal limits as were the teeth, mucosae and the nails (Figure 3). 


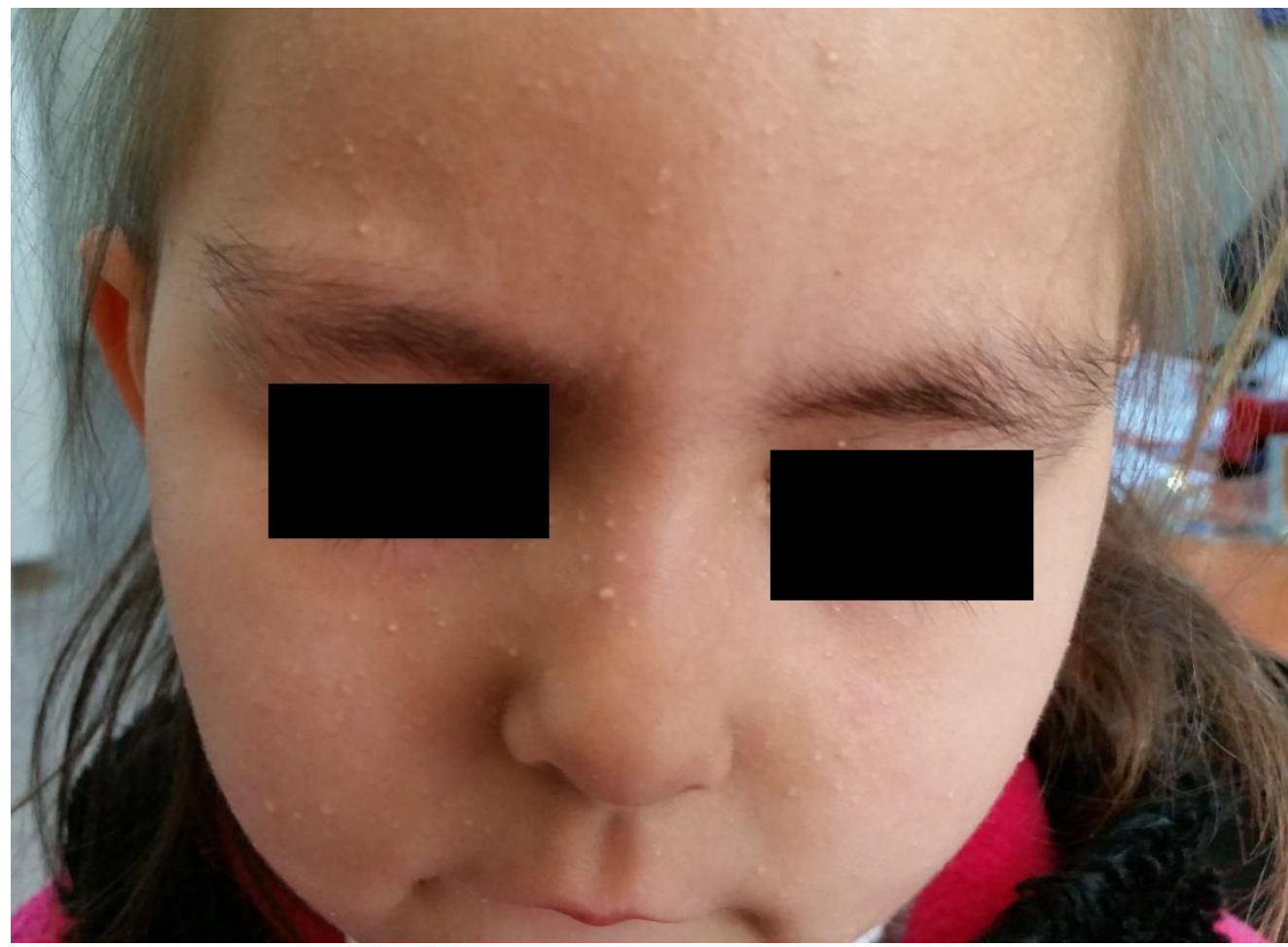

Figure 3: Case 2. Multiple milias on the face

The boy had multiple milias on his face, scalp, trunk and extremities, but most of them were on the face and scalp. He had a few, scattered dry hairs and eyebrows. The teeth, mucosae and the nails were within normal limits (Figure 4). Mental and motor development of the children was normal consistent with their ages.

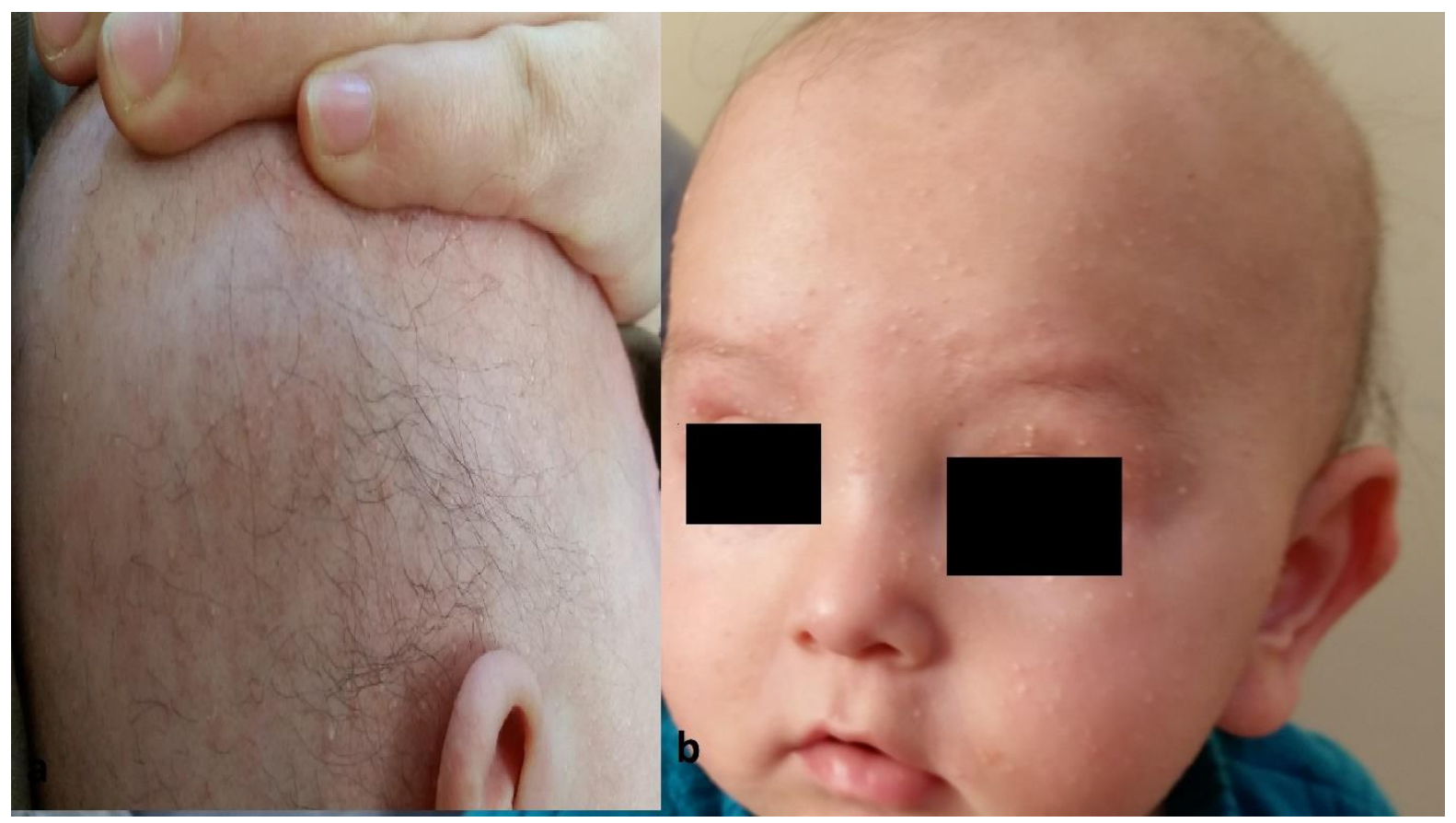

Figure 4. a-b. Case 3. Multiple milias on the scalp and hypotrichosis of scalp hair (a). Multiple milias on the face and hypotrichosis of eyebrows (b). 
Laboratory analysis and abdominal ultrasonography of all patients were normal. Light microscopic examination of hairs of the patients showed no pathologic appearance. The lack of electron microscopic examination of the hairs may be thought as the limitation of this study.

Because of presence of multiple milias on the three of the family members we thought that this might be a genodermatosis. Multiple milias, hypotrichosis, dry skin (because of hypohidrosis), follicular atrophoderma on the dorsal aspect of the hands and familial skin cancer history (although an unknown histopathologic examination result) led us to the diagnosis of Basex-Duphré-Cristol syndrome (BDCS).

We performed simple extraction of the milias and we follow up the patients closely because of basal cell carcinoma (BCC) development risk.

\section{DISCUSSION}

BDCS characterized by congenital hypotrichosis, hypohidrosis, follicular atrophoderma and multiple basal cell carcinomas was first described by Bazex et $\mathrm{al}^{2}$. The other features including multiple milia, hair shaft dystrophies, facial hyperpigmentation, long thin nose with hypoplastic nasal alae, trichoepitheliomas and hypertelorism were reported later ${ }^{1,3-5}$.

This syndrome is an X-linked dominant disorder. The localization of the mutated gene is on the distal part of Xq (between Xq24-q27.1). However, the candidate gen has not been revealed yet; but it is thought that the mutated gene is associated with cell proliferation regulation of the hair follicle ${ }^{3,6}$. Approximately 20 families with this syndrome were reported so far ${ }^{6}$. In our comprehensive review we detected only 2 families with BDCS from Turkey ${ }^{7,8}$. This case report presents the third family from Turkey with BDCS.

The most common clinical features of BDCS are hypotrichosis and follicular atrophoderma (85\%). Hypotrichosis mostly affects scalp and eyebrows but all of the body hair may be affected ${ }^{8,9}$. Hair shaft abnormalities like pili torti and trichorrhexis nodosa were reported ${ }^{5,9}$. Our patients had dry and sparse hair of scalp and eyebrows. The light microscopic appearance of the hair shaft was normal but electron microscopic examination was not applicable.

Follicular atrophoderma is especially seen on the dorsa of the hands and feet, extensor surface of the extremities and face of the patients with BDSC. It is thought that atrophoderma is originated from milias ${ }^{9}$. In our cases, the mother had follicular atrophoderma on the dorsum of her hands but the hands and the feet of the children were normal. It is known that the age of onset of the clinical symptoms can vary with intrafamilial phenotypic variation ${ }^{6}$. So children may experience the follicular atrophoderma with the increasing age. Milia is seen in $75 \%$ of the patients with BDCS. It usually appears during infancy and early childhood especially on the face and less frequently on extremities and trunk ${ }^{1,9}$. Histopathological feature is an epidermal cyst surrounded by keratinized compressed epithelium ${ }^{8}$. In our family, mother and daughter had multiple milias only on their faces but the son had multiple milias on his face, scalp, trunk and extremities.

BCC is seen $40-75 \%$ of the patients. They usually occur on the second or third decade of the life. However onset of BCC between the ages 9-50 were reported ${ }^{1,9}$. Our patients did not have any BCC-like lesions. However 4 of the family members who had also multiple milias on their skin, had skin cancer history on their faces. We are following up our patients because of $\mathrm{BCC}$ development risk.

There exist numerous genodermatosis associated with multiple milias; like BDCS, Rombo syndrome, Brooke Spiegler syndrome, generalized basaloid follicular hamartoma syndrome (GBFHS), orofaciodigital syndrome tip 1, atrichia with papular lesions, hereditary vitamin D depended rickets type IIA, pachyonychia congenita type II, basal cell nevus syndrome, familial milia and absent dermatoglyphics, Nicolau-Blaus syndrome, hypotrichosis with light-colored hair and fascial milia, KID syndrome, epidermolysis bullosa and hereditary porphyrias. Differential diagnosis of milia associated genodermatosis are given at table $1^{1,9,10}$. 
Table 1: Differential diagnosis of milia associated genodermatosis $1,9,10$

\begin{tabular}{|c|c|}
\hline Condition & Clinical Features \\
\hline BDCS* & $\begin{array}{l}\text { Multiple milias, hypotrichosis, hypohidrosis, follicular } \\
\text { atrophoderma, multiple BCCs*** }\end{array}$ \\
\hline Rombo syndrome & $\begin{array}{l}\text { Follicular atrophy, BCCs, multiple milias, atrophoderma } \\
\text { vermiculatum, trichoepithelioma, telangiectasia, acral } \\
\text { erythema, short trunk }\end{array}$ \\
\hline Brooke Spiegler syndrome & $\begin{array}{l}\text { Trichoepitheliomas, cylindromas, spiradenomas, } \\
\text { occasionally milia }\end{array}$ \\
\hline $\begin{array}{l}\text { Nevoid Basal Cell Carcinoma Syndrome } \\
\text { (Gorlin Syndrome) }\end{array}$ & $\begin{array}{l}\text { BCCs, epidermoid cysts, palmoplantar pits, skeletal } \\
\text { anomalies, internal tumors, milia }(30 \%) \text {, }\end{array}$ \\
\hline GBFHS** & $\begin{array}{l}\text { Multiple milias, comedone-like lesions, multiple skin } \\
\text { colored follicular papules on the face, scalp, neck, upper } \\
\text { trunk, axilla and lower arms; diffuse scalp hypotrichosis, } \\
\text { hypohidrosis, palmoplantar pits }\end{array}$ \\
\hline Orofaciodigital syndrome tip 1 & $\begin{array}{l}\text { Milias, patchy alopecia, facial asymmetry, nasal alar and } \\
\text { malar hypoplasia, board nasal ridge, frontal bossing, } \\
\text { micrognathia, low-set ears, hypertelorism, multilobed } \\
\text { tongue, teeth anomalies, digital anomalies }\end{array}$ \\
\hline Atrichia with papular lesions & Milia, hypotrichosis, atrophoderma, extensive hair loss \\
\hline Vitamin D depended rickets type IIA & $\begin{array}{l}\text { Generalized milia, hair loss, hypocalcemia, } \\
\text { hyperparathyroidism, osteomalacia }\end{array}$ \\
\hline Pachyonychia congenita type II & $\begin{array}{l}\text { Palmoplantar keratoderma, follicular keratoses, cutaneous } \\
\text { cysts (milia, steatocystoma vellus hair cysts, epidermal } \\
\text { inclusion cysts), nail dystrophy, alopecia, neonatal teeth }\end{array}$ \\
\hline Familial milia and absent dermatoglyphics & $\begin{array}{l}\text { Milias, absent dermatoglyphics, acral blistering, nail } \\
\text { dystrophy, digital flexion contractures, webbed toes }\end{array}$ \\
\hline
\end{tabular}

*BDCS: Bazex-Dupré-Chistol syndrome

**GBFHS: Generalized basaloid follicular hamartoma syndrome

***BCC: Basal cell carsinoma 


\section{CONCLUSION}

Multiple milias, follicular atrophoderma, hypotrichosis, hypohidrosis and family history of BCC referred us to the diagnose of BDCS in our patients. Our comprehensive physical examination of all patients revealed that multiple milias may be a feature of a genodermatosis and these patients should be examined for all of the genodermatosis mentioned above.

The manuscript was presented as a poster at " $26^{\text {th }}$ National Dermatology Congress" at 19-23 October 2016, Antalya; Turkey.

Acknowledgements: There is no financial support. The authors have no conflict of interest to declare.

\section{REFERENCES}

1. Berk DR, Bayliss SJ. Milia: a review and classification. J Am Acad Dermatol. 2008;59:1050-63. doi: 10.1016/j.jaad.2008.07.034.

2. Bazex A, Dupré A, Christol B. [Follicular atrophoderma, baso-cellular proliferations and hypotrichosis].Ann Dermatol Syphiligr (Paris). 1966;93:241-54.

3. Vabres P, Lacombe D, Rabinowitz LG, et al. The gene for Bazex-Dupré-Christol syndrome maps to chromosome Xq.J Invest Dermatol. 1995;105:87-91.

4. Kidd A, Carson L, Gregory DW, et al. J Med Genet. A Scottish family with Bazex-Dupré-
Christol syndrome: follicular atrophoderma, congenital hypotrichosis, and basal cell carcinoma. 1996;33:493-7.

5. Glaessl A, Hohenlautner U, Landthaler M, Vogt T. Sporadic Bazex-Dupré-Christol-like syndrome: early onset basal cell carcinoma, hypohidrosis, hypotrichosis, and prominent milia. Dermatol Surg. 2000;26:152-4.

6. Parren LJ, Abuzahra F, Wagenvoort T, et al. Linkage refinement of Bazex-Dupré-Christol syndrome to an $11 \cdot 4-\mathrm{Mb}$ interval on chromosome Xq25-27.1. Br J Dermatol. 2011;165:201-3. doi: 10.1111/j.13652133.2011.10219.x.

7. Hocaoğlu E, Aydın A, Basat SO. A case of basal cell carcinoma related to a rare condition, Bazex-Dupre- Christol Syndrome. Istanbul Med J 2013;14:126-8. doi:10.5152/imj.2013.34.

8. Can B, Turkoglu Z, Kavala M, et al. Generalized eruptive white papules in a 9year-old boy. Pediatr Dermatol. 2011;28:7278. doi: 10.1111/j.1525-1470.2011.01603.x.

9. Torrelo A, Sprecher E, Mediero IG, Bergman $\mathrm{R}$, Zambrano A.What syndrome is this? Bazex-Dupre-Christol syndrome. Pediatr Dermatol. 2006;23:286-90

10. Tharini G, Subashini M, Roshan SA, Prabhavathy D, Jayakumar S.Congenital hypotrichosis, eruptive milia, and palmoplantar pits: a case report with review of literature.Int J Trichology. 2012;4:32-5. doi: 10.4103/0974-7753.96086. 